\title{
Investigation of the Physical Ergonomic Conditions of the Operating Rooms in the Province of Izmir
}

\author{
Kübra YASAK*(kubra.yasak@deu.edu.tr), Asst. Prof. Dr. Fatma VURAL*(fatma.vural@deu.edu.tr) \\ *Dokuz Eylül University Faculty of Nursing, Turkey
}

\begin{abstract}
The aim of this study is to examine the physical ergonomic conditions of the operating rooms and to evaluate the risk factors in the hospitals of IIzmir. This study was descriptive and cross-sectional design. The research was conducted in a total of 58 operating rooms of a university and eight hospitals of the health ministry. In the study, the data were collected by using the form of the ergonomic conditions and risk factors in the operating room by the researcher through observation in the operating theater rooms and face to face with the head nurses in the operating room. None of the operating rooms included in the study have a surgical smoke evacuation system (n: 58). At the same time, $5.2 \%$ of the operating rooms (n:3) do not have an evacuation system for anesthetic gases. The average hourly air changes of the operating rooms are $29.27 \pm 4.40$ times, all of which are open air. The average temperature of the 0

operating rooms was found to be $20.29 \pm 2.09 \mathrm{C}$ and the average humidity was found to be $36.48 \pm 14.40 \%$. The noise level in the operating rooms ( $\mathrm{n}$ : 58) included in the study was found to be $54.29 \pm 7.85 \mathrm{~dB}$ (A). During the operation, $29.3 \%$ of the operating rooms do not have high stools used for the purpose of allowing the health personnel to rest for a short period of time. At the same time, there is no pressure absorbing mat in any operating room. No special equipment is available at any hospital for conditions such as transporting / lifting patients in operating rooms. As a result of the study, it has been found that the operating rooms which are evaluated as a result are inadequate in terms of physical and ergonomic conditions, such as surgical and anesthetic gas evacuation system, noise level in the operating room, equipment used for operations such as patient handling / lifting, high stool-pressure absorbing mat. It is important to improve the working health of the operating rooms that are inadequate in terms of physical ergonomic conditions.
\end{abstract}

Key Words: Ergonomics, Operating Room, Staff Health and Safety

\section{Introduction}

Ergonomically appropriate working environments are very important for staff safety. In terms of staff safety, ergonomics is closely related to the fact that physical conditions are sufficient. The operating room (OR) includes many ergonomic risk factors like standing for a long time, noise pollution, transport of surgical equipment that affect health. However, ergonomics is an issue that is overlooked in terms of the safety of health care workers in the OR. The operating room is one of the highest risk areas with regard to safety working in hospitals. It includes biological, chemical, physical and psychosocial risks for health care workers. One of the physical risks is the ergonomic problems that arise due to the inadequate ergonomic conditions in the OR. (Aslan ve Öntürk 2011; Sheikzadeh, Gore, Zuckerman, Nordin, 2009; Eren 2008; Parlar 2008). Unsuitable ergonomic conditions causes to the musculoskeletal system diseases on the OR workers. In addition, due to the inadequate ergonomic conditions, OR staff may experience falls, bumps, sprains and fatigue, nervousness, headache
(Korkmaz, 2015; AORN, 2013; Cebeci, 2013; Saygun, 2012, Çinal ve Demir, 2011; Resmi Gazete 2011; Devebakan, 2007). For this reason, it is important to evaluate the physical ergonomic risk factors of the OR and to make necessary improvements.

In Turkey and the World, work-related diseases and their causes have been researched and it has been found that physical ergonomic factors are also important. However, studies on the physical ergonomic status of OR environments could not been reached. It is important to examine the current physical ergonomic conditions and risk factors of OR, which are considered high risk for nurses. Therefore, this study was carried out with the aim of examining the physical ergonomic conditions of the ORs in the hospitals of İzmir province. It is thought that this study will allow to determine the adequacy and inadequacy of the current situation in the OR and to make the regulations. 


\section{Method}

This study was descriptive and cross-sectional design. The research was conducted in a total of 58 operating rooms of a university and eight hospitals of health ministry. In the study, the data were collected by using the form of the ergonomic conditions and risk factors in the operating room by the researcher through observation in the operating theater rooms and face to face with the nurses responsible for the operating room. Used form was developed by researchers after the literature search was done. The data of the study were evaluated with the SPSS 20 package program. Descriptive statistical methods (number, percentage, mean) were used for the analysis of data.

\section{Results}

The characteristics of the hospitals and operating rooms in the sample of the study are given in Table 1.

Table 1. Features of Hospitals and Operating Rooms (n:58)

\begin{tabular}{l|c|c}
\hline Hospitals & n & $\%$ \\
\hline University hospital & 36 & 62.1 \\
Hospital of health ministry & 22 & 37.9 \\
\hline Operating Rooms & Sayı & Yüzde \\
& & \\
\hline General Surgery & 14 & 24.1 \\
Urology & 11 & 19.0 \\
Orthopedics and Traumatology & 9 & 15.5 \\
Neurosurgery & 7 & 12.1 \\
Cardiovascular Surgery & 4 & 6.9 \\
Throracic Surgery & 3 & 5.2 \\
Otolaryngology & 3 & 5.2 \\
Eye Surgery & 2 & 3.4 \\
Obstetrics And Gynecology & 2 & 3.4 \\
Transplantation & 2 & 3.4 \\
Pediatric Surgery & 1 & 1.7 \\
\hline Total & 58 & 100.0 \\
\hline
\end{tabular}

None of the operating rooms included in the study have a surgical smoke evacuation system (n: 58). At the same time, $5.2 \%$ of the operating rooms (n:3) do not have an evacuation system for anesthetic gases. The average hourly air changes of the operating rooms are $29.27 \pm 4.40$ times, all of which are open air. The average temperature of the operating rooms was found to be $20.29 \pm 2.09{ }^{0} \mathrm{C}$ and the average humidity was found to be $36.48 \pm 14.40 \%$. The noise level in the operating rooms ( $\mathrm{n}$ : 58$)$ included in the study was found to be $54.29 \pm 7.85 \mathrm{~dB}(\mathrm{~A})$ (Table 2.)

Table 2. Ventilation and Noise Properties of Hospitals and Operating Rooms (n:58)

\begin{tabular}{lcc}
\hline Features & $\mathrm{X} \pm \mathrm{SS}$ & $\begin{array}{c}\text { (min- } \\
\text { max) }\end{array}$ \\
\hline Temperature in operating room & $20.29 \pm$ & $14.40-$ \\
& 2.09 & 23.20 \\
\hline Air humidity in operating room (\%) & $36.48 \pm$ & $17.00-$ \\
(n:56) & 14.40 & 80.00 \\
\hline Air pressure in operating room (Pa ) & $2.43 \pm$ & $1-10$ \\
(n:38) & 2.36 & \\
& & \\
\hline Hourly air change (number of & $29.27 \pm$ & $20-36$ \\
changes) ) (n:18) & 4.40 & \\
\hline Noise level in operating room (dBA) & $54.29 \pm$ & $45.00-$ \\
& & 7.85 \\
\hline & & \\
\hline
\end{tabular}

During the operation, $29.3 \%$ of the operating rooms do not have high stools used for the purpose of allowing the health personnel to rest for a short period of time. At the same time, there is no pressure absorbing mat in any operating room. All operating tables used in operating rooms have the ability to adjust to the position of the patient as well as the height of the healthcare personnel. However, in $5.2 \%$ of the operating tables (n:3), the ability to adjust to the size of the health personnel in charge at the tables is not working. No special equipment is available at any hospital for conditions such as transporting / lifting patients in operating rooms(Table 3.) 
Table 3. Surgical Equipment Features of Operating Rooms (n:58)

\begin{tabular}{|c|c|c|}
\hline Features & n & $\%$ \\
\hline $\begin{array}{l}\text { Booster equipment for health care workers } \\
\text { with height difference } \\
\text { Yes } \\
\text { No }\end{array}$ & $\begin{array}{c}55 \\
3\end{array}$ & $\begin{array}{r}94.8 \\
5.2\end{array}$ \\
\hline $\begin{array}{l}\text { High stool for health care workers } \\
\text { Yes } \\
\text { No }\end{array}$ & $\begin{array}{l}41 \\
17\end{array}$ & $\begin{array}{l}70.7 \\
29.3\end{array}$ \\
\hline $\begin{array}{l}\text { Pressure-absorbing mat or health care } \\
\text { workers } \\
\text { Yes } \\
\text { No }\end{array}$ & $\begin{array}{c}0 \\
58\end{array}$ & $\begin{array}{c}0 \\
100.0\end{array}$ \\
\hline $\begin{array}{l}\text { Wheeledvehicle to transport surgical } \\
\text { instrument kit }\end{array}$ & & \\
\hline $\begin{array}{l}\text { Yes } \\
\text { No }\end{array}$ & $\begin{array}{c}58 \\
0\end{array}$ & $\begin{array}{c}100.0 \\
0\end{array}$ \\
\hline $\begin{array}{l}\text { Special equipment to transport patient } \\
\text { Yes } \\
\text { No }\end{array}$ & $\begin{array}{c}0 \\
58\end{array}$ & $\begin{array}{c}0 \\
100.0\end{array}$ \\
\hline Total & 58 & 100.0 \\
\hline
\end{tabular}

\section{Conclusion}

As a result of the study, it has been found that the operating rooms which are evaluated as a result are inadequate in terms of physical ergonomic conditions, such as surgical and anesthetic gas evacuation system, noise level in the operating room, equipment used for operations such as patient handling / lifting systems, high stool-pressure absorbing mat. It is considered that hospitals should establish a protocol for physical ergonomic conditions and pass on these protocols to progress positively in terms of employee safety. It is also important to improve the working health of the operating rooms that are inadequate in terms of physical ergonomic conditions.

\section{References}

AORN-Association of Perioperative Registered Nurses. Preoperative standards and recommended practices for inpatient and ambulatory settings. 2013, 217-331

Aslan FE, Öntürk ZK. Güvenli ameliyathane ortamı; biyolojik, kimyasal, fiziksel ve psikososyal riskler, etkileri ve önlemler. Maltepe Üniversitesi Hemşirelik Bilim ve Sanatı Dergisi, 2011, Cilt:4, Sayı:1

Babayiğit M.A, Kurt M. Hastane ergonomisi. İstanbul Med J 2013; 14: 153-9

Cebeci H. Hastanelerde iş kazaları ve çalışan güveliği: karabük şehir merkezi örneği. Uluslararası İşletme ve Yönetim Dergisi. 2013, C.:1 S.:1, ss. 62-82

Çinal A, Demir H. Hastanelerde hizmet standartları. T.C. Sağlık Bakanlığı Tedavi Hizmetleri Genel Müdürlüğü Performans Yönetimi ve Kalite Geliştirme Daire Başkanlığı, 2011Ankara, Pozitif Matbaa Ltd. Şti

Devebakan N. Özel sağlık işletmelerinde iş sağlığı ve güvenliği. Dokuz Eylül Üniversitesi Sosyal Bilimler Enstitüsü, 2007, İzmir, Doktora Tezi

Eren A. Ameliyathanede hasta ve çalışan güvenliği. İstanbul Tıp Dergisi, 2008:3;141-145

Korkmaz FD. İş yeri koşulları ve çalışan güvenliğii. ın: ameliyathane hemşireliği. Editörler: Meryem Yavuz Van Giersbergen, Şenay Kaymakçı. Meta Basım Matbaacılık. 2015, 1. Bask1, ss.179-205

Parlar S. Sağlık çalışanlarında göz ardı edilen bir durum: sağlıklı çalışma ortamı. TAF Prev Med Bull 2008;7(6):547-554

Parent-Thirion A, Fernández Macías E, Hurley J, Vermeylen G. Fourth european working conditions survey. Luxembourg : Office for Official Publications of the European Communities; 2007. p. 11-62

Resmi Gazete. 06 Nisan 2011, s.2789. Hastane ve çalışan güvenliğinin sağlanmasına dair yönetmelik

Saygun M. Sağlık Çalıșanlarında İș sağlığ 1 ve güvenliği sorunları. TAF Preventive Medicine Bulletin, 2012: 11(4)

Sheikzadeh A., Gore C., Zuckerman JD., Nordin M., Perioperative nurses and tecnicans' perceptions of 
ergonomic risk factors in the surgical environment. Applied Ergonomics 2009; 40: 833-839

Türkkan A. İşe bağlı kas-iskelet sistemi hastalıkları ve sosyoekonomik eşitsizlikler. Uludağ Üniversitesi Tıp Fakültesi Dergisi 2009; 35: 101-6. 